\title{
RELATIVE EFFICIENCY OF BROWN SUGAR AGROINDUSTRY IN KOKAP DISTRICT, KULON PROGO REGENCY, D.I. YOGYAKARTA
}

\author{
Efisiensi Relatif Agroindustri Gula Semut di Kecamatan Kokap, Kabupaten \\ Kulon Progo, D.I. Yogyakarta
}

\author{
${ }^{1}$ Dian Eswin Wijayanti ${ }^{2}$ Slamet Hartono ${ }^{2}$ Dwidjono Hadi Darwanto \\ ${ }^{1}$ Agribusiness, Faculty of Agriculture, Universitas Trunojoyo \\ ${ }^{2}$ Department of Agricultural Socio-Economics, Faculty of Agriculture, Universitas Gadjah Mada \\ Jalan Flora, Bulaksumur, Yogyakarta \\ eswin.dian@gmail.com
}

Diterima tanggal : 5 April 2016 ; Disetujui tanggal : 10 Juni 2016

\begin{abstract}
Agriculture industry is the activity using agriculture product as raw material by further process become the result product and is conducted by packaging, saving to the distributor toward consumer. Coconut (Cocos Nucifera) is one of agriculture commodity that has good potential market in Kulon Progo. Besides sold as a fresh product, coconut tree also produced nira (liquid from palm tree) that is quite potential if it is further process become brown sugar (brown sugar) to increase economic value from the characteristic of agriculture commodity. Thus, agriculture industry in that region could overcome the weaknesses of agriculture product through efficient production. The efficiency of production is obtained if input and output is used optimally so that it is able to give the advantage for agent of agriculture industry. This research is aimed to (1) analyze production efficiency of brown sugar agriculture industry, (2) to analyze external factors which affecting production efficiency of brown sugar. Basic research method which is quantitative approach supported by qualitative approach. The research is conducted in sub-district of Kokap, Kulon Progo, Yogyakarta with 100 respondents that is randomly chosen. Data of production efficiency on agriculture industry of brown sugar is obtained through Data Envelopment Analysis (DEA) by classifying into 30 Decision Making Unit (DMU). The classification is conducted based on the amount of raw material which used, while linier regression is using for Ordinary Least Square (OLS) that is used to analyze external factors which affect production efficiency on agriculture industry of brown sugar. The result of research shows that the production on agriculture industry of brown sugar is more inefficient that is $28 D M U(93,33 \%)$ and the efficient production is only $2 \mathrm{DMU}(6,67 \%)$. The external factor affected toward efficiency of agriculture industry production of brown sugar are the age of farmer, the experience of flow quickly, and the amount of coconut tree for nira.
\end{abstract}

Keywords: agriculture industry, brown sugar, Data Envelopment Analysis (DEA), Kulon Progo, production efficiency

\section{INTISARI}

Industri pertanian adalah kegiatan yang menggunakan produk pertanian sebagai bahan baku dengan proses lebih lanjut menjadi produk hasil yang dilakukan dengan mengemas, menabung ke distributor terhadap konsumen. Kelapa (Cocos nucifera) merupakan salah satu komoditi 
pertanian yang memiliki potensi pasar potensial di Kulon Progo. Selain dijual sebagai produk segar, pohon kelapa juga menghasilkan nira (cair dari pohon kelapa) yang cukup potensial jika proses selanjutnya menjadi gula semut (brown sugar) untuk meningkatkan nilai ekonomi dari karakteristik komoditas pertanian. Dengan demikian, industri pertanian di wilayah tersebut dapat mengatasi kelemahan produk pertanian melalui produksi yang efisien. Efisiensi produksi diperoleh jika input dan output digunakan secara optimal sehingga mampu memberi keuntungan bagi agen industri pertanian. Penelitian ini bertujuan untuk (1) menganalisis efisiensi produksi industri pertanian gula semut, (2) menganalisis faktor eksternal yang mempengaruhi efisiensi produksi gula semut. Metode penelitian dasar yaitu pendekatan kuantitatif yang didukung oleh pendekatan kualitatif. Penelitian dilakukan di kecamatan Kokap, Kulon Progo, Yogyakarta dengan 100 responden yang dipilih secara acak. Data efisiensi produksi pada industri pertanian gula semut diperoleh melalui Data Envelopment Analysis (DEA) dengan klasifikasi menjadi 30 Decision Making Unit (DMU). Klasifikasi dilakukan berdasarkan jumlah bahan baku yang digunakan, sedangkan regresi linier digunakan untuk Ordinary Least Square (OLS) yang digunakan untuk menganalisis faktor eksternal yang mempengaruhi efisiensi produksi pada industri pertanian gula semut. Hasil penelitian menunjukkan bahwa produksi pada industri pertanian gula merah lebih tidak efisien yaitu $28 \mathrm{DMU}(93,33 \%)$ dan produksi yang efisien hanya $2 \mathrm{DMU}(6,67 \%)$. Faktor eksternal yang mempengaruhi efisiensi produksi industri pertanian gula merah adalah umur petani, pengalaman mengalir dengan cepat, dan jumlah pohon kelapa untuk nira.

\section{Kata kunci : Data Envelopment Analysis (DEA), Efisiensi Produksi, Gula Semut, Industri Pertanian, Kulon Progo}

\section{INTRODUCTION}

Agriculture is the important sector in economic matter of Indonesia and this sector holds the main role because it could provide various meals, support industrial sector either upper or lower level and export agriculture product increasing to contribute bigger currency exchange. Industrial construction as part of economy development effort is guided to create economic structure by industrial advanced point with strong agriculture (Soekartawi, 1991). It shows that the role of agriculture is dominant and the role agriculture industry and agribusiness becomes important to have a higher economic value.

Basically, the activity of agriculture industry is to increase the ability of agribusiness agent in increasing the income, absorbing more workforces, able to give positive impact toward another sector and giving additional value from that process. In the company of household field, the owner behave everything from purchasing raw material, processing even trading agriculture industry product, because the dividing job in this field is unclear (Soekartawi, 2001). The processing company of agriculture industry is able to open new opportunity in agribusiness sector because increasing demand of raw material from agriculture fresh product. On the other hand, raw material from agriculture product has some characteristics such as perishable, bulky, or volumeneous, based on natural condition, seasonal, inconsistency product, 
small offering product, technology and accommodative management toward human resource heterogeneity (either low or high technology) with high local raw material content and agriculture product which is fluctuated (Effendi, 2010). To overcome the weaknesses of agriculture product, it is necessary conducted an optimal process in order to give economic value for its product and high income. One of important sector which is necessary developed in Indonesia is farm that the potential commodity increased of its economic value is coconut (cocos nucifera).

Coconut (cocos nucifera) is one of palm family that has high potential economic value and able to grow in tropical area like Indonesia. Coconut tree has high potential economy because almost all part of coconut can financial profit (Warisno, 2003). However, from all products of coconut, nira coconut that is from its flower can be used as raw material to produce brown sugar (crystal coconut sugar). The increasing of brown sugar export is also become strategic choice to develop brown sugar production.

The demand of market toward crystal coconut sugar is quite big that is 200 ton/ month especially for exported to another country such as Singapore, Germany, Japan, America, Middle East, and Australia (Ekadila, 2015). It prove that brown sugar is mostly liked by society especially, overseas and have a high economy. Therefore, it is needed to increasing the production of brown sugar. Brown sugar which produced by farmers is organic qualified.

Kulon progo is the center of coconut production in Yogyakarta that has planting coconut tree area with 17.812,65 ha (BPS, 2011) and natural resource of this coconut tree become an employment sector as much as 5-6 people who tap nira with coconut production of 35.000 ton/year. The overflow of raw material is expected to give additional value and economic value higher if it is conducted further process become brown sugar. Therefore, brown sugar production will be more optimal and efficient. The amount of coconut tree production in Kulon Progo for last five years from 2010 till 2014 tends to be increased.

Kulon progo as industrial production center of nira coconut become brown sugar is mostly found in Kokap. Kokap is one of 12 sub districts in Kulon Progo where the main economy of society are agriculture and horticulture. Most of them are people who tap nira used as raw material of brown sugar. As a mean of aggregate, brown sugar production in Kokap is quite high. However, none of farmers could use the amount of minimum input to produce output quantity that is wanted with available technology. Thus, none of farmers are able to minimize the cost to production output targeted. The limitation of production characterizes the 
amount of minimum input combination that is needed to the variety products or maximum output obtained with the combination of some inputs and certain technology (Cooper, 2011). Farmers who are operated over limitation are technically inefficient (Constantin et al, 2009 in Lawalata, 2013).

In the mean of achieving maximum profit with various products produced, the company is faced with limitation resources such as modal, workforce, raw material, and technology used. The success of this effort can be achieved if the company could combine the internal resource with its limitation on production then delivered toward consumer. In achieving the goal of company, the exact planning is required. Good planning can give opportunity to choose the alternative or choose best combination so the allocation of limited resources will be more efficient.

\section{METHODS}

\section{The Basic Method}

The basic method used in this research are quantitative approach and supported by qualitative. Quantitative approach which used is survey method by questioner instrument. Qualitative approach uses interview and observation.

\section{Determining Location}

This research is conducted in Kokap, Kulonprogo, Yogyakarta where the location is in the plateau which producing coconut. It is conducted by the consideration that, first Kokap is one of coconut tree center that is already known by the society. Second, it is the center of brown sugar production by using superior potential commodity that is nira in that region. Third, there are many agriculture industries producing brown sugar could used as sample research. Sampling is conducted in two villages that are gathered in group of Tiwi Manunggal, Hargowilis and Hargotirto by purposive sampling method. Tiwi Manunggal is created as location of research because first, brown sugar produced has certified organic export. Second, the member of Tiwi Manunggal has organization structure and more regular management.

\section{Determining Respondent}

The decision of research sampling is conducted by simple random sampling. The respondent chosen is 100 farmers from 753 populations gathered in Tiwi Manunggal.

\section{Data Analysis Efficiency of Brown Sugar Production}

Technique of analysis used to answer the second goal in this research is Data Envelopment Analysis (DEA). The efficiency in this research is input and output-oriented. Model used in DEA is Model Charnes Cooper Rhodes (CCR). It is formulated by : 
Objective function

$\theta=\frac{u_{1} y_{1 j}+u_{2} y_{2 j}+u_{3} y_{3 j}+u_{4} y_{4 j}+u_{5} y_{5 j}+u_{6} y_{6 j}+u_{7} y_{7 j}+u_{8} y_{8 j}+u_{9} y_{9 j}+u_{0} y_{0 j}+u_{1} y_{1 j}}{v_{1} x_{1 j}+v_{2} x_{2 j}+v_{3} x_{3 j}+v_{4} x_{4 j}+v_{5} x_{5 j}}$

In which:

$\mathrm{u}_{1} \quad$ : score for output 1

$\mathrm{v}_{1}:$ score for input 1

$y_{i j}$ : value from output 1 of $\mathrm{j}$ unit

$\mathrm{x}_{\mathrm{ij}}$ : value from input 1 of $\mathrm{j}$ unit

Constraint

$\theta=\frac{u_{1} y_{1 j}}{v_{1} x_{1 j}+v_{2} x_{2 j}+v_{3} x_{3 j}+v_{4} x_{4 j}+v_{5} x_{5 j}+v 6 x 6 j} \leq 1$

$v_{1}, v_{2}, v_{3}, v_{4}, v_{5}, v 6 \geq 0$

$u_{1} \geq 0$

(TE) value with independent variable such

In which:

$\mathrm{y}_{1}=$ Brown sugar $(\mathrm{Kg})$

$\mathrm{x}_{1}=$ Nira from coconut (liter)

$\mathrm{x}_{2}=$ Cordwood (ikat)

$\mathrm{x}_{3} \quad=$ Labor (Rupiah)

$\mathrm{x}_{4}=$ Laru as support material (gram)

$\mathrm{x}_{5}=$ Depreciation cost (plant and materiel) (Rp)

$\mathrm{x}_{6}=$ Plastic for brown sugar packaging (unit)

External Factors Affecting Production Efficiency of Brown Sugar

Multiple linier regression aims to analyze external factors which affecting efficiency of production so that the dependent variable is Technical Efficiency as the age of farmer, farmer's education, experience of tapping, experience of brown sugar cultivation, family responsibility, and the amount of coconut tree for nira. Regression formula as follows:

$$
\begin{gathered}
y=\alpha+b_{1} x_{1}+b_{2} x_{2}+b_{3} x_{3}+b_{4} x_{4}+b_{5} x_{5}+ \\
b_{6} x_{6}+\mu
\end{gathered}
$$

In which :

$\mathrm{y} \quad=$ Value of technical efficiency (TE) from DEA result with CRS asumtion

$\alpha=$ Constanta

$\mathrm{b}_{1}, \mathrm{~b}_{2}, \mathrm{~b}_{3}, \ldots, \mathrm{b}_{6}=$ Regression coefficients

$\mathrm{x}_{1}=$ Age of farmers (years)

$\mathrm{x}_{2}=$ Education of farmers (years)

$\mathrm{x}_{3}=$ Coconut farming experience (years) 


$$
\begin{aligned}
x_{4}= & \text { Brown sugar production experience } \\
& \text { (years) } \\
x_{5}= & \text { Number of family members } \\
& \text { (people) } \\
x_{6}= & \text { Number of coconut plant for nira } \\
& \text { (units) }
\end{aligned}
$$

There is a classical assumption test in Ordinary Least Square in regressions that are normality test, multi-linearity, and heterogeneity test. Adjusted value of $\mathrm{R}^{2}, \mathrm{~F}$, and $t$ used in hypothesis test.

\section{RESULTS AND DISCUSSION}

Efficiency of Brown Sugar Production

In this research, the amount of

\begin{tabular}{|c|c|c|}
\hline DMU & Name of DMU & Nilai efisiensi relatif Produksi \\
\hline 1 & Farmer with number of nira 180 & 0,884615385 \\
\hline 2 & Farmer with number of nira 210 & 0,803736264 \\
\hline 3 & Farmer with number of nira 240 & 0,8625 \\
\hline 4 & Farmer with number of nira 270 & 0,896410256 \\
\hline 5 & Farmer with number of nira 300 & 0,912923077 \\
\hline 6 & Farmer with number of $h$ nira 330 & 0,897482517 \\
\hline 7 & Farmer with number of nira 360 & 0,866923077 \\
\hline 8 & Farmer with number of nira 390 & 0,885976331 \\
\hline 9 & Farmer with number of nira 420 & 0,88967033 \\
\hline 10 & Farmer with number of nira 450 & 0,909994695 \\
\hline 11 & Farmer with number of nira 480 & 0,889038462 \\
\hline 12 & Farmer with number of nira 540 & 0,917641026 \\
\hline 13 & Farmer with number of nira 585 & 0,846508876 \\
\hline 14 & Farmer with number of nira 600 & 0,902307692 \\
\hline 15 & Farmer with number of nira 630 & 0,904835165 \\
\hline 16 & Farmer with number of nira 648 & 0,886581197 \\
\hline 17 & Farmer with number of nira 675 & 0,928649573 \\
\hline 18 & Farmer with number of nira 720 & 0,909679487 \\
\hline 19 & Farmer with number of nira 750 & 0,928846154 \\
\hline 20 & Farmer with number of nira 765 & 0,926244344 \\
\hline 21 & Farmer with number of nira 810 & 0,916068376 \\
\hline 22 & Farmer with number of nira 840 & 0,94021978 \\
\hline 23 & Farmer with number of nira 870 & 0,918779841 \\
\hline 24 & Farmer with number of nira 900 & 0,920398341 \\
\hline 25 & Farmer with number of nira 969 & 0,88965468 \\
\hline 26 & Farmer with number of nira 1035 & 1 \\
\hline 27 & Farmer with number of nira 1080 & 0,963388321 \\
\hline 28 & Farmer with number of nira 1125 & 0,969656138 \\
\hline 29 & Farmer with number of nira 1200 & 0,958986012 \\
\hline 30 & Farmer with number of nira 2100 & 1 \\
\hline
\end{tabular}
respondent used in sampling are 100 farmers of brown sugar. It is then conducted by group based on nira used to produce brown sugar to determine Decision Making

Table 1. Results of Production Efficiency Analysis Brown Sugar Agroindustry

Sumber: Primary data analysis (2015) 
Unit (DMU) from DEA so that is obtained 30 DMU. In this research, used two approaches oriented that is input and output oriented in the discussion below.

\section{Input-Oriented}

The production of brown sugar agriculture industry is able to be efficient if the efficiency value is 1 or less than $100 \%$, while the production of Brown sugar agriculture industry that is inefficient if its value less than 1 or $100 \%$ (Coelli et al, 2005). From the result of the analysis by using DEA method, it is obtained the result of relative production efficiency of brown sugar agroindustry in Kokap district, Kulon Progo regency at table 1 as follows:

Based on relative production efficiency of brown sugar in Kokap the amount of inefficient is $28 \mathrm{DMU}$. They are $1,2,3,4,5,6,7,8,9,10,11,12,13,14$, $15,16,17,18,19,20,21,22,23,24,25$, 27,28 , and 29 with the efficiency less than 1 from $100 \%$, while the amount of DMU efficient is 26 and 30 with the value 1 or $100 \%$. Farmer who is inefficient means that the use of input is not optimal yet because all DMU almost uses production input excessively. Thus, it is necessary conducted of improvement by reducing the amount of input in order to obtain optimal input with targeted output. Based on the result, it is known that $93 \%$ unit of brown sugar operated is still efficient yet in Kulon Progo.
The average of nira raw material input used in producing brown sugar by using assumption of Constant Return to Scale (CRS) is 682,4 , the average of workforce input 2 , the average of wood 80.733, the average of (laru) 1361.938, the average of plastic used 21.780, and the average of reducing cost 43868.84 . The average of brown sugar output is 194.854 . Based on this estimation, it is obtained that 28 productions of brown sugar is not efficient yet (93\%) and 2 DMU producing brown sugar efficiently is $(7 \%)$.

Table 2. Brown Sugar Production Efficiency (Input Oriented)

\begin{tabular}{ll}
\hline & DMU \\
\hline $\mathrm{N}$ & 30 \\
Average & 0,910924 \\
Standard Deviasion & 0,040846 \\
maximum & 1 \\
Minimum & 0,803736 \\
\hline
\end{tabular}

Sumber: Primary data analysis (2015)

The table shows that there are $30 \mathrm{DMU}$ that becomes DEA estimation. The average of production efficiency of brown sugar by using CCR model is 0,9109924. In calculating using DEA, it is known that there is 2 DMU (7\%) that has operated in efficient level, while 28 (93\%) DMU conducts the production inefficient for 1 month. The farmers of brown sugar that is efficient is in DMU 26 and 30 where DMU 26 is farmers with 1035 liter of nira and DMU 30 is the farmers with 2100 liter of nira. The production of brown sugar with lowest efficient value is the second 
Table 3. Results of Production Efficiency Analysis Brown Sugar Agroindustry

\begin{tabular}{llll}
\hline DMU & Score & 1/Score & Production efficiency level (\%) \\
\hline 1 & 0.884615385 & 1.130434783 & 88,46 \\
2 & 0.803736264 & 1.244189226 & 80,37 \\
3 & 0.8625 & 1.15942029 & 86,25 \\
4 & 0.896410256 & 1.115560641 & 89,64 \\
5 & 0.912923077 & 1.095382541 & 91,29 \\
6 & 0.897482517 & 1.114227832 & 89,74 \\
7 & 0.866923077 & 1.15350488 & 86,69 \\
8 & 0.885976331 & 1.128698324 & 88,60 \\
9 & 0.88967033 & 1.124011858 & 88,97 \\
10 & 0.909994695 & 1.098907505 & 91,00 \\
11 & 0.889038462 & 1.124810729 & 88,90 \\
12 & 0.917641026 & 1.089750754 & 91,76 \\
13 & 0.846508876 & 1.181322522 & 84,65 \\
14 & 0.902307692 & 1.108269395 & 90,23 \\
15 & 0.904835165 & 1.10517367 & 90,48 \\
16 & 0.886581197 & 1.127928275 & 88,66 \\
17 & 0.928649573 & 1.076832456 & 92,86 \\
18 & 0.909679487 & 1.099288281 & 90,97 \\
19 & 0.928846154 & 1.076604555 & 92,88 \\
20 & 0.926244344 & 1.079628725 & 92,62 \\
21 & 0.916068376 & 1.091621571 & 91,61 \\
22 & 0.94021978 & 1.063581113 & 94,02 \\
23 & 0.918779841 & 1.088400023 & 91,88 \\
24 & 0.920398341 & 1.086486096 & 92,04 \\
25 & 0.88965468 & 1.12403163 & 88,97 \\
26 & 1 & 1 & 100 \\
27 & 0.963388321 & 1.038003034 & 96,39 \\
28 & 0.969656138 & 1.031293426 & 96,97 \\
29 & 0.958986012 & 1.042768078 & 95,90 \\
30 & 1 & 1 & 100 \\
\hline
\end{tabular}

Sumber: Primary data analysis (2015)

DMU brown sugar production with 0.8037 or $80,37 \%$.

Inefficiency of Brown sugar production shows that there is input which use is not optimal in benefit of available resources. It is known from the amount of efficient farmer that is less when compared whit inefficient farmers. In other words, all the farmers of brown sugar is not using efficient input in achieving certain output. Therefore, the farmer have to attempt to produce efficiently by the improvement suggested based on the obtained result from the use of DEA estimation. The farmers have to observe the combination of input such as nira, wood, workforce, laru, plastic and the reducing optimal cost in achieving certain output.

The allocating input that is not accurate becomes the main factor of production inefficiency of brown sugar. 
If input used is less or excessive causing input combination that is not optimal, it will affect for production inefficiency farmers. The accurate input combination is important to be observed in producing brown sugar because if it achieves full efficiency it will give maximum profit to the farmer.

\section{Output-oriented}

CCR model - output orientation views the efficiency as the increasing output proportionally by using the same input where the agriculture industry requested to produce output as much as possible from the available input. From the analysis by using Data Envelopment Analysis (DEA), it is obtained relative production efficiency of brown sugar agroindustry in Kokap district, Kulon Progo regency served in table 3 below.

The result of relative production efficiency obtained from table shows the same result with the estimation of DEA model CCR - input oriented that there are 28 DMU inefficient. They are 1, 2, 3, $4,5,6,7,8,9,10,11,12,13,14,15,16$, $17,18,19,20,21,22,23,24,25,27,28$ and 29. The efficient value is less than $100 \%$. While, DMU that achieves 100\% or 1efficiency, there are DMU 26 and 30 (the farmers with 1035 nira and farmers with 2100 nira). DMU with the lowest efficiency compared with another second DMU (the farmers with 210 nira) with
0.8037 efficiency $(80,37 \%)$. The inefficient farmers shows that output produced by agriculture industry of brown sugar is not optimal yet because all farmers are almost $93,33 \%$ producing output under targeted result by the use of excessive input. Thus, it is necessary to restore by increasing output without changing the use of input determined.

Table 4. Brown Sugar Production Efficiency (Output Oriented)

\begin{tabular}{ll} 
& DMU \\
\cline { 2 - 2 } $\mathrm{N}$ & 30 \\
Average & 0,910924 \\
Standard deviation & 0,040846 \\
Maximum & 1 \\
Minimum & 0,803736 \\
\hline
\end{tabular}

Sumber: Primary data analysis (2015)

Table 4 shows the same result toward the result obtained from CCR model of input orientation with maximum efficiency 1 and the minimum efficiency $0,8037(80,37 \%)$ from 30 DMU tested. The average of efficiency product in brown sugar agriculture industry with assumption of Constant Return to Scale (CRS) is 0,910924 . This value is same with the average of CCR - input oriented because the different between input orientation and output DEA model basically is in the standard used in determining efficiency based on either input or output views. However, whatever the orientation is will estimate the same limitation. 
Table 5. Regression Coefficient Of External Factors Affecting Production Efficiency at Brown Sugar Agroindustry, Kokap District, Kulon Progo

\begin{tabular}{lll}
\hline Variable & Regression Coefficient & Sig t \\
\hline Constanta & $13,476^{*}$ & 0,000 \\
Age of farmers $\left(\mathrm{X}_{1}\right)$ & $-2,017^{* * *}$ & 0,056 \\
Education of farmers $\left(\mathrm{X}_{2}\right)$ & $0,973^{\text {ns }}$ & 0,340 \\
Tapping nira experience $\left(\mathrm{X}_{3}\right)$ & $1,740^{* * *}$ & 0,095 \\
Nira production experience $\left(\mathrm{X}_{4}\right)$ & $1,893^{* * *}$ & 0,071 \\
Number of family member $\left(\mathrm{X}_{5}\right)$ & $-0,484^{\text {ns }}$ & 0,633 \\
Number of coconut plant for nira $\left(\mathrm{X}_{6}\right)$ & $2,186^{* *}$ & 0,039 \\
\hline Adj R & 0,480 & \\
Sig. F & 0,001 & \\
\hline
\end{tabular}

Sumber: Primary data analysis (2015)

Note:

* $\quad=$ signifikan pada $\alpha 1 \%$

** $\quad=$ signifikan pada $\alpha 5 \%$

*** $\quad=$ signifikan pada $\alpha 10 \%$

ns $\quad=$ non signifikan

\section{External Factors Affecting Production Efficiency of Brown Sugar Production}

Efficiency production is the ability to produce output in certain quality with low cost. In this characteristic, production efficiency production of brown sugar on agriculture industry could achieved as efficient as possible. Therefore, it is known the external factors affecting production efficiency of Brown sugar. Regression analysis aims to see the affect from variable independent toward dependent variable. The result of analysis by using Ordinary Least Square (OLS) could be known in table 5 below.

Independent variables each affect on brown sugar production efficiency by new equation regression model can explained and interpreted as follows:

\section{a. Constanta}

Constanta with significant value is 0,000 smaller than $\alpha=0,05$. In other words, minimum efficiency from agriculture industry of brown sugar is 13, 476 .

\section{b. The Age of Farmers}

Age has significant affect toward production efficiency value of brown sugar, where the variable of farmers age significantly affect the production efficiency of brown sugar with $90 \%$ credibility or $\alpha=10 \%$ and significant $t$ value is 0,056 with coefficient regression $-2,017$. It can be meant that if the age of brown sugar farmers is increased $1 \%$ it will decrease efficiency production 2,017\%. The age has a negative relationship. It means that the highest of age the much 
experience obtained thus, the craftsman will be more efficient in conducting brown sugar production.

\section{c. The experience of Tapping}

The experience of processing nira is independent variable which has significant affect toward brown sugar production efficiency in $90 \%$ credibility or $\alpha=10 \%$ $(\alpha=0,10)$ with significant value 0,095 and coefficient of regression 1,740. The experience of tapping (nira) is significantly affected toward the production efficiency of brown sugar with the positive relationship. It means that if the experience of tapping is increased $1 \%$ it will increase production efficiency $1,740 \%$. The most experience of tapping the more efficient producing brown sugar.

\section{d. The Experience of Processing Nira}

The experience of processing nira is independent variable that has significantly affect toward production efficiency of brown sugar $90 \%$ credibility or $\alpha=10 \%$ with significant value 0,071 and regression coefficient value is 1,893 . The experience of tapping affect significantly toward production efficiency value with positive relationship. It can be interpreted that if the experience in processing nira is $1 \%$, it will increase efficiency production $1,893 \%$. The most experience obtained in processing brown sugar the more efficient conducting brown sugar production.

\section{e. The Amount of Tree for Nira}

The amount of coconut tree that will be used as raw material of brown sugar has significant affect toward brown sugar efficiency production with $90 \%$ credibility or $\alpha=0,05$ and regression coefficient is 2,186 . The value of significant $t$ from independent variable for nira is 0,039 . The amount of tree used as raw material of brown sugar significantly affect toward production efficiency value with positive relationship. It means that if amount of tree is increased $1 \%$ it will increase efficiency production of brown sugar 2,186\%.

\section{CONCLUSIONAND SUGESSTION}

Based on the analysis by using Data Envelopment Analysis (DEA), CCR mode

1 orientation input and output, it can be concluded that only 2 DMU or 2 farmers of brown sugar production in Kokap has achieved $100 \%$, while 28 DMU or 98 farmers of brown sugar is inefficient with the percentage under $100 \%$. External variables that significantly affect production efficiency of brown sugar are the age of farmers, the experience of tapping, the experience of processing brown sugar, and the amount of tree for nira.

\section{ACKNOWLEDGEMENT}

Author would like to thank the local government that provides access to conduct 
the research and all of farmers who became respondents in this research.

\section{REFERENCES}

Badan Pusat Statistik. 2011. Badan Pusat Statistik (BPS) Kabupaten Kulon Progo. 2011. Luas Areal Komoditas Unggulan Daerah Istimewa Yogyakarta. Yogyakarta : Badan Pusat Statistik.

Coelli, J. Timothy, et al. 2005. An Introduction to Efficiency and Productivity Analysis Second Edition. Australia : Springer.

Cooper, W. William, Seiford, M. Lawrence and Zhue, Joe. 2011. Handbook on Data Envelopment Analysis Second Edition. USA : Springer.

Dinas Pertanian dan Kehutanan Kabupaten Kulon Progo. 2015. Kabupaten Kulon Progo Dalam Angka 2014. Yogyakarta : Badan Pusat Statistik.
Effendi, Mas'ud. 2010. Karakteristik Produk Pertanian. Malang : Teknologi Hasil Pertanian Universitas Brawijaya.

Ekadila. 2015. Maтpu Ekspor Gula Semut 60 Ton per Bulan. http://satelitnews. co/mampu-impor-gula-semut-60ton-per-bulan/. Akses 2 April 2015.

Lawalata, Marfin. 2013. Tesis Efisiensi Relatif Usahatani Bawang Merah di Kabupaten Bantul, Yogyakarta. Yogyakarta : Universitas Gadjah Mada.

Soekartawi. 1991. Agroindustri Hasil Pertanian. Jakarta : Rajawali Press.

Soekartawi. 2000. Pengantar Agroindustri. Jakarta : PT. Raja Grafindo Persada. Warisno. 2003. Budidaya Kelapa Genjah. Yogyakarta : Kanisius. 